\title{
Minority investor protection mechanisms and agency costs: An empirical study using a World Bank- developed approach
}

\author{
Hoang N. Pham ${ }^{a *}$ and Minh C. Nguyen ${ }^{b}$
}

${ }^{a}$ Victoria University, Melbourne, Australia

${ }^{b}$ Doimoi.org, Hanoi, Vietnam

\section{H R O N I C L E}

\begin{tabular}{l}
\hline Article history: \\
Received March 18, 2021 \\
Received in revised format May \\
182021 \\
Accepted June 202021 \\
Available online \\
June 202021 \\
\hline Keywords: \\
Agency costs \\
Controlling shareholder \\
Corporate governance \\
mechanism \\
Minority investor \\
World Bank
\end{tabular}

\section{Introduction}

Protecting minority investors is one of the main areas of business regulation employed by the World Bank (WB) to rank economies on the ease of doing business, published annually in the well-known 'Doing Business' reports. Regulators and policymakers around the world have been significantly influenced by this ranking (Lin \& Ewing-Chow, 2016). The extent of minority investor protection is measured by a comprehensive set of indicators with a focus on minority shareholders' rights in corporate governance. It is implied that protecting minority investors is a strategy to achieve sound corporate governance, promoting firm performance and economic growth (WB, 2017, 2018, 2019). ${ }^{1}$ In theory, the role of minority shareholders is highlighted in agency problems among multiple principals/owners, notably the conflicts of interest between controlling shareholders and minority shareholders of the firm (e.g., Cronqvist \& Nilsson, 2003; Gailmard, 2009; Larsén,

\footnotetext{
${ }^{1}$ In this paper, the terms 'investor' and 'shareholder' are used interchangeably.

* Corresponding author.

E-mail address: pham.hoangaus@gmail.com (H. N. Pham)

\begin{abstract}
A B S T R A C T
This study aims to examine the impact of minority investor protection mechanisms on agency costs. All relevant indicators of minority investor protection adapted from the World Bank' annual 'Doing Business' reports, along with concentrated government ownership, are employed with a panel data sample of 135 Vietnamese listed firms during the period 2014 2018. It is found that the following mechanisms are effective in mitigating agency costs and transactions; 2) minority shareholders' ability to sue and hold directors liable for their duties; 3) minority shareholders' access to internal corporate documents; 4) investors' rights to approve major corporate investment and sale of asset decisions; and 5) disclosure in annual reports of salaries, bonuses and other forms of remuneration to directors and management. Interestingly, board independence and controlling government shareholders are not confirmed to play significant roles in addressing agency problems. To the best of the authors' knowledge, this is the first attempt at testing for the impact of minority investor protection mechanisms evidence for the adoption of the minority investor protection mechanisms promoted by the World Bank. This study also provides policy implications for selecting effective mechanisms to mitigate agency conflicts between controlling shareholders and minority investors in order to enhance the financial performance of firms in an Asian emerging market.
\end{abstract}


2007; Lin, 2017). This is referred to as the principal-principal problem or type II agency problem (Kumar \& Zattoni, 2017), which contrasts with the traditional principal-agent problem as demonstrated by agency theorists such as Berle and Means (1932) and Jensen and Meckling (1976). It is also claimed that in most countries in the world, publicly traded firms often have large controlling shareholders and the main agency problem is between controlling shareholders and minority shareholders, rather than between managers and dispersed shareholders (Cronqvist \& Nilsson, 2003).

The agency problem associated with minority shareholders may cause agency costs because most agency relationships involve some forms of agency costs (Jensen \& Meckling, 1976). With a principal-principal agency problem, it is suggested that controlling shareholders has the potential to generate significant agency costs (Cronqvist \& Nilsson, 2003). This is because of the potential expropriation by controlling shareholders of benefits in various forms such as actual stealing, selling a company's assets at low prices or diverting company opportunities (Kurtulan, 2017). Consequently, protecting minority shareholders involves the protection of shareholders against directors' misuse of the firm's assets for personal gain and of the rights and role of shareholders in corporate governance (WB, 2017). Intuitively, an effective framework of minority investor protection means a lower level of agency costs. To this end, various corporate governance mechanisms can be designed to protect minority shareholders.

In practice, the WB has developed a set of minority investor protection mechanisms that covers multiple aspects of corporate governance. Based on survey findings, two groups of indicators are constructed, comprising: i) the extent of conflict-ofinterest regulation index (measured since 2004); and ii) the extent of shareholder governance index (measured since 2014). The strength of minority investor protections is determined by the overall scores for protecting minority investors, which are the simple averages of the scores for the extent of conflict of interest regulation index and the extent of shareholder governance index. According to the WB (2017), reforms aimed at increasing the involvement of minority investors in corporate decisions are being implemented by policymakers around the world. There have been 63 legislative changes introduced by 54 economies since 2013 to strengthen minority investor protections, of which 38 are in the first group, 17 in the second group and 8 in both groups of indicators abovementioned.

Regarding the benefits of protecting minority investors, existing studies focus more on the legal implications than on the effects of shareholder empowerment on economic indicators such as firm value, profitability, cost of capital or capital market size (WB, 2017). This is also the case for the studies by Lin and Ewing-Chow (2016) and McCormack (2018), which analyze the minority investor protection mechanisms used by the WB in its 'Doing Business' reports. There is a lack of understanding in the literature on the impacts of the WB-developed minority investor protection mechanisms on firm-level agency costs. Given the growing trend around the world of adopting the WB-developed indicators of minority investor protection mechanisms as mentioned above, the effectiveness of such mechanisms deserves an empirical study. Therefore, this paper attempts to fill this gap by examining the impacts of these mechanisms on firm-level agency costs in a country that has adopted them.

This paper employs a single-country setting because the minority investor protection issue is highly dependent on the specific context to be evaluated (L. Lin \& Ewing-Chow, 2016). Vietnam is selected as the context of the study due to two reasons. First, major mechanisms of minority investor protection proposed by the WB have been incorporated into recent legal documents regarding corporate governance in Vietnam. ${ }^{2}$ As recognized by the WB (2017, p. 186), for example, 'Vietnam strengthened minority investor protections by making it easier to sue directors in cases of prejudicial transactions between interested parties, by increasing shareholder rights and role in major corporate decisions, by strengthening the ownership and control structures of companies and by increasing corporate transparency requirements'. Thus, this country provides a good laboratory to test the impact of such mechanisms on agency costs.

Second, Vietnamese public firms are characterized by concentrated ownership by the government or founding family members. In a non-Anglo-Saxon and code law country, ${ }^{3}$ the ownership structure is generally more concentrated and complex, while there is less effective legal protection for investors (Brown, Beekes, \& Verhoeven, 2011; Kamarudin, Ariff, \& Jaafar, 2020; Tirole, 2006). Under such circumstances, protecting minority shareholders is a critical issue and concentrated government ownership can serve as a means of protection. While a concentrated ownership structure is usually concerned with agency problems, it can be an alternative mechanism to protect small investors (Brown et al., 2011). However, whether this mechanism works in Vietnam's context also needs to be investigated.

Based on the knowledge gap and specific context of the study, this paper addresses the two following research questions: (1) Do the minority investor protection mechanisms developed by the World Bank help reduce agency costs in practice? (2) Is government ownership concentration a mechanism to protect minority investors in the Vietnamese context? The main purpose of both research questions is to test the validity of the firm-level minority investor protection mechanisms adopted from the WB and ownership concentration by the government in reducing the agency costs of controlling shareholders. The answers to both research questions are expected to be useful for predicting and comparing the outcomes of adoption of the

\footnotetext{
${ }^{2}$ Three legal documents in this regard are: 1) Circular 96/2020/TT-BTC dated 16 November 2020 by the Ministry of Finance of Vietnam guiding the practice of information disclosure on securities markets; 2) Decree 155/2020/ND-CP dated 31 December 2020 by the Vietnamese Government on details for implementing a number of articles and/or clauses of the Securities Law; and 3) Circular 166/2020/TT-BTC dated 31 December 2020 on the guidance of a number of articles and/or clauses about corporate governance in Decree 155/2020/ND-CP.

${ }^{3}$ Basically, a code law system is characterized by a codified set of legal statutes created by legislators. It is also referred to as a civil law system and is different from a common law system.
} 
WB's approach by other countries. This is possible because one objective of the 'Doing Business' report series is 'to provide standardized, comparable measurements on the adoption of corporate governance practices across 190 economies that can be tested against economic indicators' (WB, 2017, p. 65).

To this end, this paper focuses on minority investors (i.e., shareholders who own non-controlling shares, typically less than $50 \%$, of the total voting rights of the firm) and agency costs of Vietnamese listed firms. We use a data sample of 135 firms over 5 years 2014-2018. In addition to concentrated government ownership, the explanatory variables of interest are the 6 indicators of protecting minority investors developed by the WB (WB, 2017, 2018, 2019). The dependent variable is agency costs. It is found that the following protection mechanisms have significant impacts on mitigating agency costs: 1) review and approval requirements for related-party transactions; 2) minority shareholders' ability to sue and hold directors liable for their duties; 3) minority shareholders' access to internal corporate documents; 4) investors' rights to approve major corporate investment and sale of asset decisions; and 5) disclosure in annual reports of salaries, bonuses and other forms of remuneration to directors and management. However, we have failed to confirm that the independence of the board and government ownership concentration play roles in reducing agency costs.

This research contributes to the literature in several aspects. First, to the authors' knowledge, this is the first empirical study that examines the impacts of the minority investor protection mechanisms developed by the WB (2017) on agency costs at the firm level. Hence, this study provides important practical implications for corporate regulators and policymakers on the adoption of the minority investor protection mechanisms promoted by the WB in its 'Doing Business' reports. Second, we contribute to the corporate governance literature with a negative view on the role of the independence of the board of directors; that is, it may not serve as a means to reduce agency costs. Third, this study provides empirical evidence and interesting policy implications for selecting effective mechanisms to ensure minority shareholders' rights in order to address potential agency conflicts and promote the financial performance of firms in an Asian emerging market.

This paper is structured as follows: Section 2 reviews the related literature on agency problems and minority investor protection mechanisms. Section 3 presents the methodology and data employed in this research, including empirical model specifications. Section 4 reports the empirical results and discusses the implications of the research. Section 5 concludes the research and discusses some limitations of this study.

\section{Review of related literature}

\subsection{Principal-principal agency problems, agency costs and need to protect minority investors}

On the foundation of agency theory, Kumar and Zattoni (2017) summarize that agency problems and conflicts of interest take different forms such as those between shareholders and managers (the principal-agent problem, type I), between controlling shareholders and minority shareholders (the principal-principal problem, type II) and between shareholders and creditors. Intuitively, protecting the interests of minority investors addresses the agency conflicts of type II between controlling principals/shareholders and minority principals/shareholders.

The severity of principal-principal problems can be measured by agency costs. Since most agency relationships involve some forms of agency costs as suggested in agency theory (Jensen \& Meckling, 1976), a principal-principal problem is also associated with agency costs of its own type. Cronqvist and Nilsson (2003) claim that controlling shareholders has the potential to generate significant agency costs. While agency costs with a principal-agent problem arise as a consequence of the separation of ownership and control, and consist of monitoring expenditures by the principal, bonding expenditures by the agent and residual loss (Berle \& Means, 1932; Fama \& Jensen, 1983; Jensen \& Meckling, 1976), a principal-principal agency problem incurs agency costs because of the potential expropriation of benefits by controlling shareholders in various forms such as actual stealing, selling a company's assets at low prices or diverting company opportunities (Kurtulan, 2017).

In particular, agency costs can be viewed as the financial loss, or the loss in dollar revenues (Ang, Cole, \& Lin, 2000), due to controlling shareholders' expropriation. Cronqvist and Nilsson (2003) estimate that the agency costs of controlling vote ownership are a loss of $6-25 \%$ of firm value for medium-sized firms. Therefore, it is likely that more severe conflicts of interest between controlling principles and minority principals mean a higher level of agency costs.

In most countries in the world, publicly traded firms often have large controlling shareholders and the main agency problem is between controlling shareholders and minority shareholders, rather than between managers and dispersed shareholders (Cronqvist \& Nilsson, 2003). Consequently, protecting minority investors is a critical issue in order to sustain the proper functioning of firms and the economy. Empirical studies show that there are important benefits of protecting minority investors. Klapper and Love (2004) imply that firm performance is higher in countries with strong legal systems of shareholder protection. The WB (2018) reports that in economies with better investor protection and stronger corporate governance, companies were found to experience smaller declines in their market value during the 2008 global financial crisis.

In short, principal-principal problems give rise to the need to protect minority shareholders. Corporate governance mechanisms designed to protect minority shareholders aim to reduce the financial losses in terms of agency costs. Hence, it is likely that an effective framework of minority investor protection will have impacts on minimizing agency costs. 


\subsection{Minority investor protection mechanisms and agency costs}

Prior studies have discussed various corporate governance mechanisms concerning agency problems. For instance, the board of directors can reduce agency problems because directors have incentives to maintain their independence, monitor the CEO and replace the CEO if their performance is poor (Hermalin \& Weisbach, 2003). Ownership structure can also be a mechanism to control agency problems. If the contract between a firm and managers does not mitigate agency conflict, an increase in the level of insider shareholding can be an effective corporate governance mechanism for this purpose, since it increases managerial monitoring and alignment with shareholders' interests (Agrawal \& Knoeber, 1996; Bhagat, Bolton, $\&$ Romano, 2010). The above arguments are more suitable for agency problems of type I rather than for principal-principal agency problems.

For type II and the principal-principal relationship, the relevant issues of investor protection are examined extensively in the literature (e.g., Berkman, Cole, \& Fu, 2010; Bianchi, Ciavarella, Novembre, \& Signoretti, 2010; Defond \& Hung, 2004; La Porta, Lopez-de-Silanes, Shleifer, \& Vishny, 2000; La Porta, Lopez-de-Silanes, Shleifer, \& Vishny, 2002). Nevertheless, the WB (2017) claims that the existing studies on the issue discuss more the legal implications and less the effects of shareholder empowerment on economic indicators such as firm value, profitability, cost of capital or capital market size. In fact, such gaps (i.e., fewer economic indicators) are being filled by recent research on the issue. For example, protecting investors is shown to have economic implications for cross-border mergers (Kurtulan, 2017), option repricing and firm performance (Gulen \& O'Brien, 2017) and foreign strategic ownership (Anderson, Chi, \& Liao, 2019).

The WB (WB, 2017, 2018, 2019) has developed a comprehensive set of indicators to measure the extent of minority investor protection, consisting of two main groups of indices: 1) the extent of conflict of interest regulation index (measured since 2004); and 2) the extent of shareholder governance index (measured since 2014). The first main group consists of the following sub-indices (and accompanying mechanisms/indicators): i) the extent of disclosure index (Review and approval requirements for related-party transactions; Internal, immediate and periodic disclosure requirements for related-party transactions); ii) the extent of director liability index (Minority shareholders' ability to sue and hold interested directors liable for prejudicial related party transactions; Available legal remedies (damages, disgorgement of profits, fines, imprisonment, rescission of transactions)); and iii) the ease of shareholder suit index (Access to internal corporate documents; Evidence obtainable during trial; Allocation of legal expenses).

The second main group consists of the following sub-indices (and accompanying mechanisms/ indicators): i) the extent of shareholder rights index (Shareholders' rights and role in major corporate decisions); ii) the extent of ownership and control index (Governance safeguards protecting shareholders from undue board control and entrenchment); and iii) the extent of corporate transparency index (Corporate transparency on significant owners, executive compensation, annual meetings and audits). The data for the above indicators are constructed from questionnaires administered to corporate and securities lawyers, and are based on securities regulations, company laws, civil procedure codes and court rules of evidence.

The WB (2017) states that protecting minority shareholders involves the protection of shareholders from conflicts of interest and against directors' misuse of a firm's assets for personal gain, and of the rights and role of shareholders in corporate governance. This view reveals that agency theory is the main theoretical basis for developing the abovementioned set of minority investor protection mechanisms. As discussed in Section 2.1, the principal-principal agency problem implies that there is potential expropriation of benefits by controlling shareholders. Therefore, the minority investor protection mechanisms developed by the WB are expected to mitigate the agency problems and minimise agency costs associated with controlling shareholders.

The development of minority investor protection indicators by the WB has attracted the attention of researchers. Two recent studies (L. Lin \& Ewing-Chow, 2016; McCormack, 2018) analyze the minority investor protection mechanisms used by the WB in its 'Doing business' reports. However, the focus of these two works is on the legal aspects of minority investor protection mechanisms. The effects of the WB-developed mechanisms of minority investor protection on agency costs at the firm level remain unknown in the corporate governance literature.

Overall, empirical studies have implied that minority investor protection mechanisms have impacts on agency costs from an agency theory perspective. It is also indicated that the minority investor protection indicators developed by the WB are based on an agency view. However, there is still a lack of understanding in the literature on the effects of the minority investor protection mechanisms developed by the WB on agency costs in practice. In this paper, therefore, we attempt to fill this gap by seeking the answers to research question (1) as stated in Section 1.

\subsection{Minority investor protection issue in Vietnam}

According to Vu, Tower, and Scully (2011), one of several problems facing Vietnam's stock market is weak shareholder protection. Various cases of corporate scandals and violations of laws relating to the rights of shareholders can be observed among Vietnamese listed firms in recent years. For example, with regards to listed companies on the Vietnamese stock markets, corporate scandals associated with minority investors often take typical forms such as misuse of the company's assets, failure to meet information disclosure obligations and violations by major shareholders and stakeholders in share trading. 
According to the International Finance Corporation (IFC (2010), a potential agency problem in Vietnamese listed firms is the limited separation of ownership and control between board members (directors) and managers. Typically, the CEO is also the chairman and/or a member of the board of directors. A typical consequence of this fact is a weak accountability and control structure for managers, which may adversely influence their corporate risk-taking appetites and incentives to work towards firm performance.

Therefore, protecting minority shareholders in the firm is indeed an issue of growing concern in this country. This is featured by the presence of the IFC - a member of the World Bank Group - in Vietnam with a corporate governance project to assist corporate regulators to adopt good corporate governance principles and recommendations. As of 2017, the WB acknowledges that 'Vietnam strengthened minority investor protections by making it easier to sue directors in cases of prejudicial transactions between interested parties, by increasing shareholder rights and role in major corporate decisions, by strengthening the ownership and control structures of companies and by increasing corporate transparency requirements' (WB, 2017, p. 186).

Major effective mechanisms of minority investor protection introduced by the WB (WB, 2017, 2018, 2019) have been incorporated into regulatory documents and recommendations in recent years, for example, Decree 71/2017/ND-CP of the government on the guidelines of corporate governance for public companies (2017), the revised Securities Law (2019) and the 'Vietnam corporate governance code of best practices' (2019). Most recently, Circular 96/2020/TT-BTC, issued in November 2020 by the Ministry of Finance, became legally binding as of 1 January 2021. This document provides details of guidance on the practice of information disclosure on the Vietnamese securities markets. The information disclosure and transparency requirements as stipulated in Circular 96 are consistent with the minority investor protection mechanisms developed by the WB. In addition, Decree 155/2020/ND-CP issued by the Vietnamese Government in December 2020 also came in full force as of 1 January 2021. There is a separate chapter in Decree 155 solely for corporate governance requirements for Vietnamese public firms, which covers the main mechanisms of protecting minority investors like the ones used by the WB.

It can be said that the recent developments in the corporate governance legal framework in Vietnam provide a good institutional background to explore the impact of minority investor protection mechanisms on agency costs in order to address the weak investor protection problem among Vietnamese public firms. It is still uncertain whether such mechanisms work in practice because minority investors are perhaps not fully aware of or interested in exercising their rights. Since the minority investor protection issue is highly dependent on the specific context to be evaluated (L. Lin \& Ewing-Chow, 2016), an empirical research using the Vietnamese context is expected to provide new insights into and practical implications on the issue.

Furthermore, Vietnamese public firms are characterized by ownership concentration by the government or founding family members. In a non-Anglo-Saxon and code law country, ownership structure is generally more concentrated and complex, while there is less effective legal protection for investors (Brown et al., 2011; Tirole, 2006). Hu and Izumida (2008) also claim that a ubiquitous feature of firms in many non-Anglo-Saxon countries is ownership concentration. Hence, code (or civil) law countries can be classified as countries with weak investor protection (Kamarudin et al., 2020).

In such an institutional environment of weak minority investor protection, principal-principal agency conflict is a concern (Dharwadkar, George, \& Brandes, 2000). La Porta and Shleifer (1999) suggest that while ownership concentration minimizes principal-agent conflict, it also causes another agency problem known as principal-principal conflict. Ownership concentration has some negative effects due to majority shareholders' practice of tunnelling of resources at the expense of minority shareholders. In contrast, Gaur, Bathula, and Singh (2015) argue that ownership concentration may not lead to principal-principal conflict because under this structure, managers make strategic decisions in the best interests of the firm rather than their own. Brown et al. (2011) also suggest that while a concentrated ownership structure is usually concerned with agency problems, it can be an alternative mechanism to protect small investors.

Whether or not ownership concentration can protect minority investors is thus a practical issue that needs more empirical evidence. Therefore, we also attempt to test for the impact of ownership concentration by the Vietnamese Government on agency costs to answer research Eq. (2) of this paper.

\section{Methodology and data}

\subsection{Empirical model}

Based on the issues discussed above, we specify an empirical model in the following form:

$$
\begin{aligned}
\text { Agency costs }_{i t}= & \alpha_{i t}+\beta_{1} \text { Minority investor protection mechanisms } s_{i t}+\beta_{2} \text { Controls }_{i t} \\
& +\beta_{3} \text { Firm fixed effects } \text { Sit }_{i}+\beta_{4} \text { Year fixed effects } \\
\text { it } & +\varepsilon_{i t}
\end{aligned}
$$

where the $i$ and $t$ subscripts stand for firm and year. Minority investor protection mechanisms are the minority investor protection mechanisms adopted from the WB (2017) and concentrated government ownership. The controls are control variables at the firm level. $\varepsilon$ is the error term. 
It is plausible to assume that firms are not homogenous; hence, firm fixed effects are controlled in the model to capture the unobserved heterogeneity of firms across years. We also include year fixed effects to control for time-varying macroeconomic conditions that may affect the agency costs of all firms in the sample in a particular year. The models are estimated with heteroscedasticity-robust standard errors clustered by firm.

\subsection{Variable measurement}

\section{Dependent variables}

Agency costs: In the finance and economics literature, the operating expense ratio and asset utilization ratio are the most common proxies for agency costs (Ang et al., 2000). The operating expense ratio can be calculated as total operating expenses scaled by annual sales. The asset utilization ratio, or efficiency ratio, shows the loss in revenues due to inefficient asset utilization (Ang et al., 2000). For Vietnamese listed firms, the operating expense ratio is not a good measure of agency costs (Tuan, Nha, Long, \& Phuong, 2019). Therefore, we employ the asset utilization ratio as the proxy for agency costs in this research. Following previous studies (Ang et al., 2000; Chen \& Yur-Austin, 2007; Davidson \& Singh, 2003; McKnight \& Weir, 2009), this ratio is defined as annual sales divided by total assets. It should be noted that this is an indirect (or inverse) measure of agency costs in the sense that a higher value of the asset utilization ratio implies a lower level of agency costs, ceteris paribus. It also measures the ability of managers to deploy assets efficiently and hence it is likely that the asset utilization ratio is more inclusive than the operating expense ratio in determining the size of the agency costs of Vietnamese firms.

For convenience, the asset utilization ratio measure of agency costs is converted into a direct form by multiplying it by minus one $(-1)$ value. In this form, it is more intuitive to interpret the results because a higher value of the converted asset utilization ratio means a higher level of agency costs and vice versa.

\section{Independent variables}

Minority investor protection mechanisms: This study considers all indices that contain mechanisms/indicators of minority investor protection as documented in the 'Doing Business' reports (WB, 2017, 2018, 2019). There are 6 sub-indices as such as listed in Section 2.2. One mechanism is selected from each sub-index and defined as a dummy variable at the firm level. The selected mechanisms are those adopted from the WB and can be found in the current legal or corporate documents in Vietnam. A value of 1 is assigned if there is a clear statement and/or specific information in corporate documents (including corporate charters, annual reports, corporate websites and internal corporate governance code) about a relevant indicator, and 0 otherwise. The corporate documents used to find relevant information are publicly available on either corporate websites or stock exchange websites. In addition, we employ concentrated government ownership as another independent variable of interest. Concentrated government ownership is also defined as a dummy variable, taking a value of 1 if the Vietnamese government owns more than $50 \%$ of the common equity of the firm, and 0 otherwise.

\section{Table 1}

Mechanisms of minority investor protection

\begin{tabular}{lll}
\hline \multicolumn{1}{c}{ Denotation } & \multicolumn{1}{c}{ Variable name } & Sub-index group \\
\hline M1. & Review and approval requirements for related-party transactions & Extent of disclosure \\
M2. & Minority investors' ability to make claims and hold directors liable for their duties & Extent of director liability \\
M3. & Minority investors' access to internal corporate documents & Ease of shareholder suit \\
M4. & Investors' rights to approve major corporate investment and sale of asset decisions & Extent of shareholder rights \\
M5. & $\begin{array}{l}\text { Separation of roles between CEO and chairman of the board of directors (i.e., no } \\
\text { dual roles by the same individual) }\end{array}$ & Extent of ownership and control \\
M6. & $\begin{array}{l}\text { Disclosure in annual reports of salaries, bonuses, and other forms of remuneration } \\
\text { to directors and management }\end{array}$ & Extent of corporate transparency \\
GOVCON & Concentrated government ownership & Not applicable \\
\hline
\end{tabular}

Notes: Variables M1-M6 in this table are adapted from the WB (2017). The sub-index group is the relevant group of indicators that a variable belongs to. This is an adaption of an original work by the World Bank. Views and opinions expressed in the adaption are the sole responsibility of the authors of the adaption and are not endorsed by the World Bank.

It should be noted that the proxies M1-M3 in the above list reflect the extent of conflict of interest regulation, while the other three proxies M4-M6 show the extent of shareholder governance. Since the WB holds that protecting minority shareholders involves the protection of shareholders against directors' misuse of a firm's assets for personal gain (WB, 2017), the dummy variables from M1-M6 are expected to have negative effects on agency costs. Likewise, GOVCON is expected to be negatively related to agency costs.

\section{Control variables}

Financial leverage: This ratio is calculated as long-term liabilities divided by the total assets of the firm. It is common in the literature that financial leverage is used to capture the effect of creditors on agency costs (e.g. Ang et al., 2000; Davidson $\&$ Singh, 2003). The negative impact of agency costs may be mitigated by debt due to the monitoring role of creditors (Jensen \& Meckling, 1976). In this paper, it is thus expected that financial leverage has a negative impact on agency costs. Long-term (i.e. over 1-year) liabilities are used to better measure the monitoring effect and commitment of creditors in the firm.

Firm size: This variable is defined as the natural logarithm of the total assets of the firm. Following previous studies (e.g., Chen \& Yur-Austin, 2007; Davidson \& Singh, 2003), we also employ firm size as a control variable for agency costs. Due 
to economies of scale, firm size may have a negative correlation with agency costs, meaning that a firm is more efficient as it grows.

Firm age: This variable is defined as the difference between the observed year and the initial year of listing on national stock exchanges. It shows how many years a firm has been traded on stock exchanges. Older listed firms on stock exchanges may have more experience than young firms in corporate governance practices to minimize agency costs. Hence, we expect that firm age has a negative relation with agency costs.

Foreign ownership: This variable is calculated as the ratio of common equity held by foreign investors over the total common equity of a firm. Different owners of a firm have different levels of power, incentives and ability to monitor managers (Douma, George, \& Kabir, 2006). Since foreign shareholders may help strengthen the monitoring role of shareholders of firms in Vietnam (Pham \& Kalyebara, 2020), it is expected that foreign ownership has a negative impact on agency costs.

Profitability: This variable is defined as the return on equity ratio (ROE). Prior authors such as Allam (2018) also control for the impact of profitability on agency costs. Since ROE reflects corporate earnings that belong to shareholders, profitability may be closely related to the principal-principal problems between controlling shareholders and minority shareholders. It is expected that profitability is negatively associated with agency costs because a higher ratio of profitability implies a firm is more efficient.

\subsection{Data sample}

Initially, the dataset covers 150 firms that are randomly selected from listed firms on the Hanoi Stock Exchange (HNX) and Hochiminh Stock Exchange (HSX) during the period 2014-2018. Next, financial companies (securities firms, insurance companies and commercial banks) and firms with missing information are excluded. Finally, a balanced panel data sample of non-financial firms is obtained with 675 firm-year observations (135 firms over 5 years 2014-2018). Corporate governance data (on the minority investor protection mechanisms) are manually collected from company sources (including websites, annual reports, charters and internal corporate governance codes) by a financial data mining company in Vietnam. ${ }^{4}$ Financial data is sourced from FiinGroup's database of another financial information vendor. ${ }^{5}$ To ensure the quality of data before using them in regression, we double-checked the main data entries on a random basis by comparing them with the relevant information on corporate documents, which are downloadable from company websites and stock exchanges.

Table 2 below shows a summary of the statistics of the variables employed in this study.

Table 2

Summary statistics

\begin{tabular}{|c|c|c|c|c|c|c|}
\hline Variable & Obs & Mean & Std.Dev. & Min & Max & Kurtosis \\
\hline Agency costs & 675 & -1.054 & 1.010 & -6.556 & -0.0404 & 14.378 \\
\hline M1 & 675 & 0.890 & 0.313 & 0 & 1 & 7.244 \\
\hline M2 & 675 & 0.895 & 0.307 & 0 & 1 & 7.624 \\
\hline M3 & 675 & 0.892 & 0.311 & 0 & 1 & 7.367 \\
\hline M4 & 675 & 0.895 & 0.307 & 0 & 1 & 7.624 \\
\hline M5 & 675 & 0.302 & 0.460 & 0 & 1 & 1.741 \\
\hline M6 & 675 & 0.917 & 0.276 & 0 & 1 & 10.144 \\
\hline GOVCON & 675 & 0.216 & 0.412 & 0 & 1 & 2.899 \\
\hline Financial leverage & 675 & 0.126 & 0.140 & 0 & 0.580 & 3.996 \\
\hline Firm size & 675 & 28.66 & 1.453 & 25.75 & 31.92 & 2.268 \\
\hline Firm age & 675 & 6.631 & 3.718 & 0 & 18 & 2.641 \\
\hline Foreign ownership & 675 & 0.174 & 0.172 & 0 & 0.577 & 2.328 \\
\hline Profitability & 675 & 0.146 & 0.111 & -0.0929 & 0.555 & 4.466 \\
\hline
\end{tabular}

Notes: Definitions of investor protection mechanisms (M1-GOVCON) are defined in Table I. Accounting-based variables are winsorized at the $1^{\text {st }}$ and $99^{\text {th }}$ percentile.

It can be seen from Table II that the first four independent variables (M1-M4) have similar statistics. This trend suggests that once firms have the review and approval requirements for related-party transactions in place, they also tend to ensure the following rights of minority investors: i) ability to make claims and hold directors liable for their duties; ii) access to internal corporate documents; and iii) rights to approve major corporate investment and sale of asset decisions.

In contrast, there are large discrepancies in the other two minority investor protection mechanisms. As for board independence, the number of companies with separated CEO/chairman roles is small (the mean value shows about $30 \%$ of total observations), meaning that most of the firms in the sample dataset of this research have these two roles held by a

\footnotetext{
${ }^{4}$ http://vietfis.vn

${ }^{5}$ www.fiingroup.vn
} 
single person. On the contrary, most of the firms disclose in annual reports the salaries, bonuses and other forms of remuneration to directors and management (nearly $92 \%$ ).

As some variables have relatively high Kurtosis values, a Spearman correlation matrix is employed and presented in Table III. There are indications that the correlation between minority investor protection mechanisms (except for M5 and GOVCON) and agency costs is statistically significant at the $10 \%$ level or better. Most of the coefficients of correlation are below 0.2 . However, the first four dummy variables from (2) to (5) are shown to be highly correlated, suggesting that there is a potential multicollinearity issue among minority investor protection mechanisms. This confirms that there is a common trend among them as abovementioned. Consequently, all the minority investor protection mechanisms presented in Table 1 are not tested simultaneously but alternatively against agency costs in model (1) to avoid the potential multicollinearity problem among them.

\section{Table 3}

Spearman correlation matrix

\begin{tabular}{|c|c|c|c|c|c|c|c|c|c|c|c|}
\hline & (1) & (2) & (3) & (4) & (5) & (6) & (7) & (8) & (9) & (10) & (11) \\
\hline Agency costs (1) & 1 & & & & & & & & & & \\
\hline M1 (2) & $-0.1584 *$ & 1 & & & & & & & & & \\
\hline M2 (3) & $-0.1430 *$ & $0.9771^{*}$ & 1 & & & & & & & & \\
\hline M3 (4) & $-0.1286^{*}$ & $0.9619^{*}$ & $0.9846^{*}$ & 1 & & & & & & & \\
\hline M4 (5) & $-0.1430^{*}$ & $0.9771^{*}$ & $1.0000^{*}$ & $0.9846^{*}$ & 1 & & & & & & \\
\hline M5 (6) & -0.0371 & 0.00380 & -0.00570 & 0.000600 & -0.00570 & 1 & & & & & \\
\hline M6 (7) & $-0.1281^{*}$ & $0.1695^{*}$ & $0.1770 *$ & $0.1720^{*}$ & $0.1770^{*}$ & $-0.0828 *$ & 1 & & & & \\
\hline GOVCON (8) & -0.00330 & -0.0114 & 0.0159 & 0.0207 & 0.0159 & $-0.3144 *$ & 0.0276 & 1 & & & \\
\hline Financial leverage (9) & $0.5453^{*}$ & $-0.1262 *$ & $-0.1062 *$ & $-0.1034 *$ & $-0.1062 *$ & $-0.0803^{*}$ & -0.0536 & $0.1589^{*}$ & 1 & & \\
\hline Firm size (10) & $0.3044 *$ & -0.0177 & -0.0247 & -0.0158 & -0.0247 & $-0.1687^{*}$ & $-0.1485^{*}$ & $0.0738^{*}$ & $0.4691^{*}$ & 1 & \\
\hline Firm age (11) & 0.0226 & $0.1082^{*}$ & $0.1158^{*}$ & $0.1026^{*}$ & $0.1158^{*}$ & $-0.1517^{*}$ & $0.1676^{*}$ & -0.0400 & -0.0547 & $0.1253^{*}$ & 1 \\
\hline Foreign ownership (12) & -0.0239 & $0.1296^{*}$ & $0.1262 *$ & $0.1226^{*}$ & $0.1262 *$ & $-0.1513^{*}$ & $0.1662 *$ & $-0.0812^{*}$ & 0.0136 & $0.2996^{*}$ & $0.4020 *$ \\
\hline \multirow[t]{2}{*}{ Profitability (13) } & $-0.4246^{*}$ & 0.0578 & $0.0660 *$ & 0.0572 & $0.0660^{*}$ & $-0.0993^{*}$ & $0.1194 *$ & $0.0865^{*}$ & $-0.2319 *$ & 0.0531 & $0.0634^{*}$ \\
\hline & (12) & (13) & & & & & & & & & \\
\hline Foreign ownership (12) & 1 & & & & & & & & & & \\
\hline Profitability (13) & $0.2866^{*}$ & 1 & & & & & & & & & \\
\hline
\end{tabular}

Note: Definitions of minority investor protection mechanisms (M1-GOVCON) are presented in Table I. * denotes p<0.1.

\section{Results and discussion}

\subsection{Empirical results}

In addition to the assumption that firms are not homogenous, we also perform the Hausman test for firm fixed effects in the empirical model. When M1 is employed as a proxy for the minority investor protection mechanisms, the null hypothesis that the difference in coefficients is not systematic is rejected (chi-square statistic $=31.72, \mathrm{p}<0.01$ ). The results of the test confirm that unobserved firm fixed effects are present.

Table 4

Minority investor protection mechanisms (extent of conflict-of-interest indicators) and agency costs

\begin{tabular}{|c|c|c|c|}
\hline \multirow[t]{2}{*}{ Dependent variable } & \multicolumn{3}{|c|}{ Agency costs } \\
\hline & (1) & (2) & (3) \\
\hline M1 & $\begin{array}{c}-0.310 \\
(0.101)^{* * *}\end{array}$ & & \\
\hline M2 & & $\begin{array}{c}-0.306 \\
(0.103)^{* * *}\end{array}$ & \\
\hline M3 & & & $\begin{array}{c}-0.285 \\
(0.106)^{* * *}\end{array}$ \\
\hline Financial leverage & $\begin{array}{c}2.182 \\
(0.322)^{* * *}\end{array}$ & $\begin{array}{c}2.212 \\
(0.328)^{* * *}\end{array}$ & $\begin{array}{c}2.216 \\
(0.328)^{* * *}\end{array}$ \\
\hline Firm size & $\begin{array}{c}0.088 \\
(0.042)^{* *}\end{array}$ & $\begin{array}{c}0.087 \\
(0.042)^{* *}\end{array}$ & $\begin{array}{c}0.088 \\
(0.042)^{* *}\end{array}$ \\
\hline Firm age & $\begin{array}{l}-0.004 \\
(0.024)\end{array}$ & $\begin{array}{l}-0.004 \\
(0.024)\end{array}$ & $\begin{array}{l}-0.004 \\
(0.025)\end{array}$ \\
\hline Foreign ownership & $\begin{array}{r}0.437 \\
(0.525)\end{array}$ & $\begin{array}{c}0.433 \\
(0.524)\end{array}$ & $\begin{array}{c}0.433 \\
(0.525)\end{array}$ \\
\hline Profitability & $\begin{array}{c}-2.020 \\
(0.580)^{* * *}\end{array}$ & $\begin{array}{c}-2.009 \\
(0.578)^{* * *}\end{array}$ & $\begin{array}{c}-2.015 \\
(0.579)^{* * *}\end{array}$ \\
\hline Firm effects & YES & YES & YES \\
\hline Year effects & YES & YES & YES \\
\hline VIF & 1.44 & 1.44 & 1.44 \\
\hline Adjusted $R^{2}$ & 0.22 & 0.22 & 0.22 \\
\hline$N$ & 675 & 675 & 675 \\
\hline
\end{tabular}

Notes: Definitions of minority investor protection mechanisms (M1-M3) are presented in Table I. Heteroscedasticity-robust standard errors are clustered by firms and presented in parentheses under the coefficients. Statistical significance at the $10 \%, 5 \%$ and $1 \%$ levels is indicated by $*$, $* *$ and $* * *$, respectively. 
Tables 4-6, below present the results of the fixed-effects regressions of agency costs on the minority investor protection mechanisms. As already discussed, such mechanisms are tested separately from each other to avoid potential multicollinearity problems and to obtain the individual pure impact of each mechanism on agency costs. The low values of variance inflation factor scores (VIF) reported in these tables confirm that the multicollinearity is not a problem in this model setting. The three indicators for the extent of conflict of interest are presented in Table 4. As expected, it is found that the estimated coefficients of the three minority investor protection mechanisms are all significantly negative at the $1 \%$ level. This shows that there is a significant difference in terms of agency costs between those firms having such mechanisms mentioned in their official documents and the other firms. By definitions, these are: i) review and approval requirements for related-party transactions (extent of disclosure); ii) minority investors' ability to make claims and hold directors liable for their duties (extent of director liability); and iii) minority investors' access to internal corporate documents (ease of shareholder suit). On average, the firms with these protection mechanisms incur lower levels of agency costs (about 30\%), which means they are more efficient. Table 5 provides results of the empirical model when the three minority investor protection mechanisms of shareholder governance are employed alternatively. It is found that the impacts of two mechanisms are statistically significant at the $1 \%$ and $5 \%$ levels, respectively: i) investors' rights to approve major corporate investment and sale of asset decisions (shareholders' rights in major corporate decisions); and ii) disclosure in annual reports of salaries, bonuses and other forms of remuneration to directors and management (corporate transparency). As expected, this result indicates that firms are more efficient (have lower agency costs) when shareholders' rights to approve major corporate decisions are ensured and remunerations publicly disclosed.

However, the result for board independence (M5) is not statistically significant. Intuitively, it does not make any significant difference in terms of agency costs for firms having dual roles of chairman/CEO and the other firms.

Table 5

Minority investor protection mechanisms (extent of shareholder governance indicators) and agency costs

\begin{tabular}{|c|c|c|c|}
\hline \multirow[t]{2}{*}{ Dependent variable } & \multicolumn{3}{|c|}{ Agency costs } \\
\hline & (1) & (2) & (3) \\
\hline M4 & $\begin{array}{c}-0.306 \\
(0.103)^{* * *}\end{array}$ & & \\
\hline M5 & & $\begin{array}{l}-0.015 \\
(0.138)\end{array}$ & \\
\hline M6 & & & $\begin{array}{c}-0.251 \\
(0.103)^{* *}\end{array}$ \\
\hline Financial leverage & $\begin{array}{c}2.212 \\
(0.328)^{* * *}\end{array}$ & $\begin{array}{c}2.252 \\
(0.331)^{* * *}\end{array}$ & $\begin{array}{c}2.306 \\
(0.340)^{* * *}\end{array}$ \\
\hline Firm size & $\begin{array}{c}0.087 \\
(0.042)^{* *}\end{array}$ & $\begin{array}{c}0.090 \\
(0.044)^{* *}\end{array}$ & $\begin{array}{c}0.079 \\
(0.041)^{*}\end{array}$ \\
\hline Firm age & $\begin{array}{l}-0.004 \\
(0.024)\end{array}$ & $\begin{array}{l}-0.004 \\
(0.024)\end{array}$ & $\begin{array}{l}-0.001 \\
(0.025)\end{array}$ \\
\hline Foreign ownership & $\begin{array}{r}0.433 \\
(0.524)\end{array}$ & $\begin{array}{r}0.385 \\
(0.524)\end{array}$ & $\begin{array}{r}0.433 \\
(0.524)\end{array}$ \\
\hline Profitability & $\begin{array}{c}-2.009 \\
(0.578) * * *\end{array}$ & $\begin{array}{c}-2.043 \\
(0.576) * * *\end{array}$ & $\begin{array}{c}-1.976 \\
(0.575)^{* * *}\end{array}$ \\
\hline Firm effects & YES & YES & YES \\
\hline Year effects & YES & YES & YES \\
\hline VIF & 1.44 & 1.43 & 1.44 \\
\hline Adjusted $R^{2}$ & 0.22 & 0.22 & 0.22 \\
\hline$N$ & 675 & 675 & 675 \\
\hline
\end{tabular}

Notes: Definitions of minority investor protection mechanisms (M4-M6) are presented in Table I Heteroscedasticity-robust standard errors are clustered by firms and presented in parentheses under the coefficients. Statistical significance at the $10 \%, 5 \%$ and $1 \%$ levels is indicated by $* * *$ and $* * *$, respectively.

Furthermore, we test for the effect of concentrated government ownership (GOVCON) on agency costs. This test is also to answer research question (2). Using the same fixed-effects estimation techniques, the results for controlling government ownership are presented in Table 6. It is found that the estimated coefficient on GOVCON is not significant. This suggests that government controlling ownership is not helpful to mitigate agency problems in a firm, or a firm's asset utilization is not efficient with the presence of controlling government owners. This evidence is in sharp contrast with the argument by Brown et al. (2011) as mentioned above. Instead, it is consistent with the negative view of government ownership in the privatization literature (e.g. Djankov \& Murrell, 2002; Megginson, Nash, \& Randenborgh, 2012). It also supports the finding that investments by government-controlled firms do not have any significant impacts on firm growth in Vietnam (Pham \& Kalyebara, 2020).

In terms of control variables, we find that agency costs are significantly influenced by financial leverage and firm size. It is implied that firms with a higher level of financial leverage and larger firms incur more agency costs. Interestingly, this suggests that creditors such as banks do not play an effective monitoring role in mitigating agency costs in Vietnamese listed firms. In contrast, the impact of firm age and foreign ownership on agency costs is not statistically significant. The result for profitability meets our expectation that profitability is negatively associated with agency costs. 
Table 6

Concentrated government ownership and agency costs

\begin{tabular}{lc}
\hline Dependent variable & Agency costs \\
\hline GOVCON & -0.146 \\
& $(0.209)$ \\
Financial leverage & 2.307 \\
& $(0.353)^{* * *}$ \\
Firm size & 0.093 \\
& $(0.043)^{* *}$ \\
Firm age & -0.003 \\
Foreign ownership & $(0.024)$ \\
Profitability & 0.318 \\
Firm effects & $(0.482)$ \\
Year effects & -1.962 \\
VIF & $(0.560)^{* * *}$ \\
Adjusted $R^{2}$ & YES \\
$N$ & YES \\
\hline
\end{tabular}

Notes: Heteroscedasticity-robust standard errors are clustered by firms and presented in parentheses under the coefficients. Statistical significance at the $10 \%, 5 \%$ and $1 \%$ levels is indicated by $*, * *$ and $* * *$, respectively.

\subsection{Robustness tests}

Several additional regressions are conducted to check for the robustness of the above tests. First, endogeneity is a challenging issue in research on corporate governance as well as financial and accounting decisions. A common solution is to use lagged values of the endogenous variables as instruments (McKnight \& Weir, 2009). Hence, all the right-hand side independent variables are lagged by one-year periods to mitigate potential endogenous issues. The results are provided in Table 7, Table 8 and Table 9. For convenience, the results reported earlier are reused and presented beside the ones for lagged variables. It is shown that the magnitudes of the impact of the minority investor protection mechanisms on agency costs slightly decrease, but the overall results are all consistent with the previous tests.

Table 7

Robustness tests using one-year lagged values of independent variables (extent of conflict of interest indicators)

\begin{tabular}{|c|c|c|c|c|c|c|}
\hline \multirow{2}{*}{$\begin{array}{l}\text { Dependent } \\
\text { variable }\end{array}$} & \multicolumn{6}{|c|}{ Agency costs } \\
\hline & $\mathrm{t}$ & $\mathrm{t}-1$ & $\mathrm{t}$ & $\mathrm{t}-1$ & $\mathrm{t}$ & $\mathrm{t}-1$ \\
\hline M1 & $\begin{array}{r}-0.310 \\
(0.101)^{* * *}\end{array}$ & $\begin{array}{c}-0.282 \\
(0.103)^{* * *}\end{array}$ & & & & \\
\hline M2 & & & $\begin{array}{c}-0.306 \\
(0.103)^{* * *}\end{array}$ & $\begin{array}{c}-0.276 \\
(0.104)^{* * *}\end{array}$ & & \\
\hline M3 & & & & & $\begin{array}{c}-0.285 \\
(0.106)^{* * *}\end{array}$ & $\begin{array}{c}-0.252 \\
(0.108)^{* *}\end{array}$ \\
\hline $\begin{array}{l}\text { Financial } \\
\text { leverage }\end{array}$ & $\begin{array}{r}2.182 \\
(0.322)^{* * *}\end{array}$ & $\begin{array}{c}2.031 \\
(0.343)^{* * *}\end{array}$ & $\begin{array}{c}2.212 \\
(0.328)^{* * *}\end{array}$ & $\begin{array}{c}2.054 \\
(0.348)^{* * *}\end{array}$ & $\begin{array}{c}2.216 \\
(0.328)^{* * *}\end{array}$ & $\begin{array}{c}2.058 \\
(0.348)^{* * *}\end{array}$ \\
\hline Firm size & $\begin{array}{r}0.088 \\
(0.042)^{* *}\end{array}$ & $\begin{array}{c}0.089 \\
(0.040)^{* *}\end{array}$ & $\begin{array}{c}0.087 \\
(0.042)^{* *}\end{array}$ & $\begin{array}{c}0.088 \\
(0.040)^{* *}\end{array}$ & $\begin{array}{c}0.088 \\
(0.042)^{* *}\end{array}$ & $\begin{array}{c}0.089 \\
(0.040)^{* *}\end{array}$ \\
\hline Firm age & $\begin{array}{l}-0.004 \\
(0.024)\end{array}$ & $\begin{array}{l}-0.007 \\
(0.024)\end{array}$ & $\begin{array}{l}-0.004 \\
(0.024)\end{array}$ & $\begin{array}{l}-0.007 \\
(0.024)\end{array}$ & $\begin{array}{l}-0.004 \\
(0.025)\end{array}$ & $\begin{array}{l}-0.007 \\
(0.024)\end{array}$ \\
\hline $\begin{array}{l}\text { Foreign } \\
\text { ownership }\end{array}$ & $\begin{array}{r}0.437 \\
(0.525)\end{array}$ & $\begin{array}{r}0.580 \\
(0.523)\end{array}$ & $\begin{array}{r}0.433 \\
(0.524)\end{array}$ & $\begin{array}{r}0.578 \\
(0.523)\end{array}$ & $\begin{array}{r}0.433 \\
(0.525)\end{array}$ & $\begin{array}{r}0.577 \\
(0.524)\end{array}$ \\
\hline Profitability & $\begin{array}{c}-2.020 \\
(0.580)^{* * *}\end{array}$ & $\begin{array}{c}-1.930 \\
(0.582)^{* * *}\end{array}$ & $\begin{array}{c}-2.009 \\
(0.578)^{* * *}\end{array}$ & $\begin{array}{c}-1.923 \\
(0.581)^{* * *}\end{array}$ & $\begin{array}{c}-2.015 \\
(0.579)^{* * *}\end{array}$ & $\begin{array}{c}-1.933 \\
(0.581)^{* * *}\end{array}$ \\
\hline Firm effects & YES & YES & YES & YES & YES & YES \\
\hline Year effects & YES & YES & YES & YES & YES & YES \\
\hline Adjusted $R^{2}$ & 0.22 & 0.21 & 0.22 & 0.20 & 0.22 & 0.21 \\
\hline$N$ & 675 & 540 & 675 & 540 & 675 & 540 \\
\hline
\end{tabular}

Notes: Definitions of M1-M3 are presented in Table 1. $\mathrm{t}$ and $\mathrm{t}-1$ denote the current period and one-year lagged period, respectively. Heteroscedasticityrobust standard errors are clustered by firms and presented in parentheses under the coefficients. Statistical significance at the $10 \%, 5 \%$ and $1 \%$ levels is indicated by $*, * *$ and $* * *$, respectively. 
Table 8

Robustness tests using one-year lagged values of independent variables (extent of shareholder governance indicators)

\begin{tabular}{|c|c|c|c|c|c|c|}
\hline \multirow{2}{*}{$\begin{array}{l}\text { Dependent } \\
\text { variable }\end{array}$} & \multicolumn{6}{|c|}{ Agency costs } \\
\hline & $\mathrm{t}$ & $\mathrm{t}-1$ & $\mathrm{t}$ & $\mathrm{t}-1$ & $\mathrm{t}$ & $\mathrm{t}-1$ \\
\hline M4 & $\begin{array}{r}-0.306 \\
(0.103)^{* * *}\end{array}$ & & & & & \\
\hline M5 & & $\begin{array}{c}-0.276 \\
(0.104)^{* * *}\end{array}$ & $\begin{array}{c}-0.015 \\
(0.138)\end{array}$ & $\begin{array}{c}-0.054 \\
(0.159)\end{array}$ & & \\
\hline M6 & & & & & $\begin{array}{c}-0.251 \\
(0.103)^{* *}\end{array}$ & $\begin{array}{c}-0.223 \\
(0.112)^{* *}\end{array}$ \\
\hline $\begin{array}{l}\text { Financial } \\
\text { leverage }\end{array}$ & 2.212 & 2.054 & 2.252 & 2.081 & 2.306 & 2.144 \\
\hline & $(0.328)^{* * *}$ & $(0.348)^{* * *}$ & $(0.331)^{* * *}$ & $(0.343)^{* * *}$ & $(0.340)^{* * *}$ & $(0.359)^{* * *}$ \\
\hline Firm size & $\begin{array}{r}0.087 \\
(0.042)^{* *}\end{array}$ & $\begin{array}{c}0.088 \\
(0.040)^{* *}\end{array}$ & $\begin{array}{c}0.090 \\
(0.044)^{* *}\end{array}$ & $\begin{array}{c}0.089 \\
(0.042)^{* *}\end{array}$ & $\begin{array}{c}0.079 \\
(0.041)^{*}\end{array}$ & $\begin{array}{c}0.081 \\
(0.040)^{* *}\end{array}$ \\
\hline Firm age & $\begin{array}{c}-0.004 \\
(0.024)\end{array}$ & $\begin{array}{l}-0.007 \\
(0.024)\end{array}$ & $\begin{array}{l}-0.004 \\
(0.024)\end{array}$ & $\begin{array}{l}-0.008 \\
(0.024)\end{array}$ & $\begin{array}{l}-0.001 \\
(0.025)\end{array}$ & $\begin{array}{l}-0.004 \\
(0.024)\end{array}$ \\
\hline $\begin{array}{l}\text { Foreign } \\
\text { ownership }\end{array}$ & $\begin{array}{r}0.433 \\
(0.524)\end{array}$ & $\begin{array}{r}0.578 \\
(0.523)\end{array}$ & $\begin{array}{r}0.385 \\
(0.524)\end{array}$ & $\begin{array}{r}0.532 \\
(0.521)\end{array}$ & $\begin{array}{r}0.433 \\
(0.524)\end{array}$ & $\begin{array}{r}0.579 \\
(0.524)\end{array}$ \\
\hline Profitability & $\begin{array}{c}-2.009 \\
(0.578)^{* * *}\end{array}$ & $\begin{array}{c}-1.923 \\
(0.581)^{* * *}\end{array}$ & $\begin{array}{c}-2.043 \\
(0.576)^{* * *}\end{array}$ & $\begin{array}{c}-1.994 \\
(0.585)^{* * *}\end{array}$ & $\begin{array}{c}-1.976 \\
(0.575)^{* * *}\end{array}$ & $\begin{array}{c}-1.902 \\
(0.580)^{* * *}\end{array}$ \\
\hline Firm effects & YES & YES & YES & YES & YES & YES \\
\hline Year effects & YES & YES & YES & YES & YES & YES \\
\hline$R^{2}$ & 0.22 & 0.21 & 0.21 & 0.20 & 0.21 & 0.20 \\
\hline$N$ & 675 & 540 & 675 & 540 & 675 & 540 \\
\hline
\end{tabular}

Table 9

Robustness tests using one-year lagged values of independent variables (concentrated government ownership)

\begin{tabular}{|c|c|c|}
\hline \multirow[t]{2}{*}{ Dependent variable } & \multicolumn{2}{|c|}{ Agency costs } \\
\hline & $\mathrm{t}$ & $\mathrm{t}-1$ \\
\hline GOVCON & $\begin{array}{l}-0.146 \\
(0.209)\end{array}$ & $\begin{array}{l}-0.154 \\
(0.207)\end{array}$ \\
\hline Financial leverage & $\begin{array}{l}2.307 \\
(0.353)^{* * *}\end{array}$ & $\begin{array}{l}2.153 \\
(0.374)^{* * *}\end{array}$ \\
\hline Firm size & $\begin{array}{c}0.093 \\
(0.043)^{* *}\end{array}$ & $\begin{array}{l}0.096 \\
(0.043)^{* *}\end{array}$ \\
\hline Firm age & $\begin{array}{l}-0.003 \\
(0.024)\end{array}$ & $\begin{array}{l}-0.007 \\
(0.024)\end{array}$ \\
\hline Foreign ownership & $\begin{array}{c}0.318 \\
(0.482)\end{array}$ & $\begin{array}{c}0.458 \\
(0.478)\end{array}$ \\
\hline Profitability & $\begin{array}{l}-1.962 \\
(0.560) * * *\end{array}$ & $\begin{array}{l}-1.886 \\
(0.562)^{* * *}\end{array}$ \\
\hline Firm effects & YES & YES \\
\hline Year effects & YES & YES \\
\hline Adjusted $R^{2}$ & 0.21 & 0.20 \\
\hline$N$ & 675 & 540 \\
\hline
\end{tabular}

Notes: $\mathrm{t}$ and $\mathrm{t}-1$ denote the current period and one-year lagged period, respectively. Heteroscedasticity-robust standard errors are clustered by firms and presented in parentheses under the coefficients. Statistical significance at the $10 \%, 5 \%$ and $1 \%$ levels is indicated by $* * *$ and $* * *$, respectively.

Second, due to the key role of the board of directors in corporate governance, an alternative measure of board independence is employed for robustness tests, namely, independent directors. This is also a dummy variable, taking a value of 1 if there is at least one independent director on the board, and 0 otherwise. In Table 10, it is shown that the effect of board independence on agency costs remains insignificant across both columns $t$ and $t-1$, where the latter uses lagged values of the explanatory variables to mitigate potential endogeneity issues. The results are consistent with those reported earlier with chairman/CEO separation employed as a proxy for board independence. Therefore, it can be inferred that the independence of the board of directors in Vietnamese listed firms does not contribute to lowering agency costs, at least in the period of study from 2014-2018. This finding implies that board independence is not an effective channel to protect minority investors in Vietnam. 
Table 10

Robustness test using an alternative proxy for board independence

\begin{tabular}{|c|c|c|c|}
\hline \multirow[t]{2}{*}{ Dependent variable } & \multicolumn{3}{|c|}{ Agency costs } \\
\hline & & $\mathrm{t}$ & $\mathrm{t}-1$ \\
\hline M5 & $\begin{array}{l}-0.015 \\
(0.138)\end{array}$ & & \\
\hline Independent director & & $\begin{array}{c}0.431 \\
(0.351)\end{array}$ & $\begin{array}{c}0.613 \\
(0.421)\end{array}$ \\
\hline Financial leverage & $\begin{array}{l}2.252 \\
(0.331)^{* * *}\end{array}$ & $\begin{array}{l}2.147 \\
(0.306) * * *\end{array}$ & $\begin{array}{l}1.938 \\
(0.316)^{* * *}\end{array}$ \\
\hline Firm size & $\begin{array}{l}0.090 \\
(0.044)^{* *}\end{array}$ & $\begin{array}{l}0.087 \\
(0.042)^{* *}\end{array}$ & $\begin{array}{l}0.087 \\
(0.041)^{* *}\end{array}$ \\
\hline Firm age & $\begin{array}{l}-0.004 \\
(0.024)\end{array}$ & $\begin{array}{c}0.002 \\
(0.023)\end{array}$ & $\begin{array}{c}0.001 \\
(0.023)\end{array}$ \\
\hline Foreign ownership & $\begin{array}{c}0.385 \\
(0.524)\end{array}$ & $\begin{array}{c}0.461 \\
(0.544)\end{array}$ & $\begin{array}{c}0.629 \\
(0.537)\end{array}$ \\
\hline Profitability & $\begin{array}{l}-2.043 \\
(0.576) * * *\end{array}$ & $\begin{array}{l}-1.950 \\
(0.565) * * *\end{array}$ & $\begin{array}{l}-1.882 \\
(0.564) * * *\end{array}$ \\
\hline Firm effects & YES & YES & YES \\
\hline Year effects & YES & YES & YES \\
\hline Adjusted $R^{2}$ & 0.21 & 0.23 & 0.23 \\
\hline$N$ & 675 & 675 & 540 \\
\hline
\end{tabular}

Notes: $\mathrm{t}$ and $\mathrm{t}-1$ denote the current period and one-year lagged period, respectively. Heteroscedasticity-robust standard errors are clustered by firms and presented in parentheses under the coefficients. Statistical significance at the $10 \%, 5 \%$ and $1 \%$ levels is indicated by $* * *$ and $* * *$, respectively.

Third, another proxy for firm size is employed for robustness checks. The natural logarithm of market capitalization, instead of total assets, is used for testing all model specifications. The estimated coefficients are consistent, and this confirms that our previous results are robust (results in detail are available upon request).

To sum up, among minority investor protection mechanisms promoted by the WB, we find that the following mechanisms help reduce agency costs and, hence, mitigate the agency problems associated with minority investors in practice: i) review and approval requirements for related-party transactions; ii) minority investors' ability to make claims and hold directors liable for their duties; iii) minority investors' access to internal corporate documents; iv) investors' rights to approve major corporate investment and sale of asset decisions; and v) disclosure in annual reports of salaries, bonuses and other forms of remuneration to directors and management. This is empirical evidence as to how to address principal-principal conflicts of interest between controlling shareholders and minority shareholders in agency theory. However, the study fails to support two other agency views that board independence and concentrated government ownership function as mechanisms to protect minority shareholders, at least from the Vietnamese perspective.

\section{Conclusions}

A comprehensive framework of minority investor protection indicators developed by the WB has been adopted by a growing number of countries around the world in recent years. Using a panel data sample of Vietnamese listed firms, we find empirical evidence that not all minority investor protection mechanisms adopted from the WB result in lower agency costs, but there is a set of effective mechanisms to consider as aforementioned. Theoretically, these five mechanisms are likely to be good corporate governance mechanisms in terms of mitigating principal-principal agency problems and ensuring the rights of minority shareholders of a firm. Practically, these findings confirm the validity of a selected number of minority investor protection mechanisms promoted by the WB in its 'Doing Business' annual reports. A practical implication for corporate regulators and policymakers in those countries with similar conditions to Vietnam is that these five mechanisms could be 'safe' to be adopted. It also means that some adopted mechanisms may not work effectively in practice to protect minority investors. For investors, the quality of minority investor protection needs to be evaluated before making decisions about buying shares of listed firms on Vietnam's stock markets. Furthermore, this study provides empirical evidence for the Vietnamese Government with regards to designing a better legal framework for corporate governance of public firms. As concentrated government ownership is not confirmed to be a means to mitigate agency costs, the current process of privatizing state-owned enterprises should be intensified to provide more room for private shareholders in these firms. Overall, the findings of this study are useful for predicting and comparing the outcomes of the adoption of the WB's approach by other countries.

\section{References}

Agrawal, A., \& Knoeber, C. R. (1996). Firm Performance and Mechanisms to Control Agency Problems between Managers and Shareholders. Journal of Financial \& Quantitative Analysis, 31(3), 377-397.

Allam, B. S. (2018). The impact of board characteristics and ownership identity on agency costs and firm performance: UK evidence. Corporate Governance: The International Journal of Business in Society, 18(6), 1147-1176.

Anderson, H., Chi, J., \& Liao, J. (2019). Foreign strategic ownership and minority shareholder protection. Emerging Markets Review, 39, 34-49. 
Ang, J. S., Cole, R. A., \& Lin, J. W. (2000). Agency costs and ownership structure. The Journal of Finance, 55(1), 81-106. doi:10.1111/0022-1082.00201

Berkman, H., Cole, R. A., \& Fu, L. J. (2010). Political connections and minority-shareholder protection: Evidence from securities-market regulation in China. Journal of Financial and Quantitative Analysis, 45(6), 1391-1417.

Berle, A. A., \& Means, G. C. (1932). The Modern Corporation and Private Property.

Bhagat, S., Bolton, B., \& Romano, R. (2010). The effect of corporate governance on performance. In B. H. Kent \& A. Ronald (Eds.), Corporate Governance: A Synthesis of Theory, Research, and Practice (pp. 97-122). Chichester: Wiley.

Bianchi, M., Ciavarella, A., Novembre, V., \& Signoretti, R. (2010). Comply or explain? Investor protection through corporate governance codes. Investor Protection Through Corporate Governance Codes (March 1, 2010). ECGIFinance Working Paper(278).

Brown, P., Beekes, W., \& Verhoeven, P. (2011). Corporate governance, accounting and finance: A review. Accounting and Finance, 51(1), 96-172. doi:10.1111/j.1467-629X.2010.00385.x

Chen, X., \& Yur-Austin, J. (2007). Re-measuring agency costs: The effectiveness of blockholders. Quarterly Review of Economics and Finance, 47(5), 588-601. doi:10.1016/j.qref.2007.09.003

Cronqvist, H., \& Nilsson, M. (2003). Agency Costs of Controlling Minority Shareholders. Journal of Financial and Quantitative Analysis, 38(4), 695-719.

Davidson, W. N., \& Singh, M. (2003). Agency costs, ownership structure and corporate governance mechanisms. Journal of banking \& finance, 27(5), 793-816. doi:10.1016/s0378-4266(01)00260-6

Defond, M. L., \& Hung, M. (2004). Investor protection and corporate governance: Evidence from worldwide CEO turnover. Journal of Accounting Research, 42(2), 269-312.

Dharwadkar, B., George, G., \& Brandes, P. (2000). Privatization in emerging economies: An agency theory perspective. Academy of Management Review, 25(3), 650-669.

Djankov, S., \& Murrell, P. (2002). Enterprise restructuring in transition: A quantitative survey. Journal of economic literature, 40(3), 739-792.

Douma, S., George, R., \& Kabir, R. (2006). Foreign and Domestic Ownership, Business Groups, and Firm Performance: Evidence from a Large Emerging Market. Strategic Management Journal, 27(7), 637-657. doi:10.1002/smj.535

Fama, E. F., \& Jensen, M. C. (1983). Separation of ownership and control. Journal of law and economics, 301-325.

Gailmard, S. (2009). Multiple principals and oversight of bureaucratic policy-making. Journal of Theoretical Politics, 21(2), 161-186.

Gaur, S. S., Bathula, H., \& Singh, D. (2015). Ownership concentration, board characteristics and firm performance. Management decision, 53(5).

Gulen, H., \& O'Brien, W. J. (2017). Option repricing, corporate governance, and the effect of shareholder empowerment. Journal of Financial Economics, 125(2), 389-415.

Hermalin, B. E., \& Weisbach, M. S. (2003). Boards of directors as an endogenously determined institution: a survey of the economic literature. Economic Policy Review, 9(1), 7-26.

Hu, Y., \& Izumida, S. (2008). Ownership concentration and corporate performance: a causal analysis with Japanese panel data. Corporate Governance: An International Review, 16(4), 342-358. doi:10.1111/j.1467-8683.2008.00690.x

IFC. (2010). Corporate Governance Manual (2nd ed.). Hanoi.

Jensen, M. C., \& Meckling, W. H. (1976). Theory of the firm: managerial behavior, agency costs and ownership structure. Journal of Financial Economics, 3(4), 305-360.

Kamarudin, K. A., Ariff, A. M., \& Jaafar, A. (2020). Investor protection, cross-listing and accounting quality. Journal of Contemporary Accounting \& Economics, 16(1), 100179.

Klapper, L. F., \& Love, I. (2004). Corporate governance, investor protection, and performance in emerging markets. Journal of Corporate Finance, 10(5), 703-728.

Kumar, P., \& Zattoni, A. (2017). Agency Conflicts and Corporate Governance. Corporate Governance: An International Review, 25(4), 220-221.

Kurtulan, G. (2017). Minority shareholder protection in cross-border mergers: a must for or an impediment to the European single market? European Business Organization Law Review, 18(1), 101-121.

La Porta, R., Lopez-de-Silanes, F., Shleifer, A., \& Vishny, R. (2000). Investor protection and corporate governance. Journal of Financial Economics, 58(1-2), 3-27.

La Porta, R., Lopez-de-Silanes, F., Shleifer, A., \& Vishny, R. (2002). Investor protection and corporate valuation. The Journal of Finance, 57(3), 1147-1170.

La Porta, R., \& Shleifer, A. (1999). Corporate ownership around the world. The Journal of Finance, 54(2), 471-517. doi:10.1111/0022-1082.00115

Larsén, M. F. (2007). Principal-agent analysis with one agent and two principals: European Union trade negotiations with South Africa. Politics \& Policy, 35(3), 440-463.

Lin, L., \& Ewing-Chow, M. (2016). The Doing Business index on minority investor protection: the case of Singapore. Singapour Journal of Legal Studies, 46.

Lin, Y.-H. (2017). Controlling Controlling-Minority Shareholders: Corporate Governance and Leveraged Corporate Control. Colum. Bussiness Letter Review, 453.

McCormack, G. (2018). Why 'doing business' with the world bank may be bad for you. European Business Organization Law Review, 19(3), 649-676. 
McKnight, P. J., \& Weir, C. (2009). Agency costs, corporate governance mechanisms and ownership structure in large UK publicly quoted companies: A panel data analysis. Quarterly Review of Economics and Finance, 49(2), $139-158$. doi:10.1016/j.qref.2007.09.008

Megginson, W. L., Nash, R. C., \& Randenborgh, M. (2012). The financial and operating performance of newly privatized firms: An international empirical analysis. The Journal of Finance, 49(2), 403-452.

Pham, H., \& Kalyebara, B. (2020). Investments in subsidiaries, joint ventures, affiliates and firm growth: Evidence from Vietnam. Accounting, 6(5), 879-892.

Tirole, J. (2006). The theory of corporate finance: Princeton, NJ : Princeton University Press.

Tuan, T. M., Nha, P. V. T., Long, T. P., \& Phuong, T. T. (2019). Impact of Agency Costs on Firm Performance: Evidence from Vietnam. Organizations \& Markets in Emerging Economies, 10(2).

Vu, K. A., Tower, G., \& Scully, G. (2011). Corporate communication for Vietnamese listed firms. Asian Review of Accounting, 19(2), 125-146. doi:10.1108/13217341111181069

WB. (2017). Doing business 2017: equal opportunity for all : comparing business regulation for domestic firms in 190 economies (14th edition. ed.): World Bank.

WB. (2018). Doing business 2018: reforming to create jobs : comparing business regulation for domestic firms in 190 economies (15th edition. ed.): The World Bank.

WB. (2019). Doing Business 2019: Training for Reform : comparing business regulation for domestic firms in 190 economies (16th edition. ed.): World Bank.

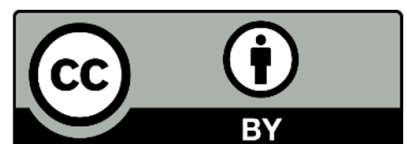

(C) 2022 by the authors; licensee Growing Science, Canada. This is an open access article distributed under the terms and conditions of the Creative Commons Attribution (CC-BY) license (http://creativecommons.org/licenses/by/4.0/). 